\title{
The Role of Private Commercial Bank in Corporate Social Responsibility with Reference to Islami Bank Bangladesh Limited
}

\author{
Md. Tota Miah, Kumar Biswazit Saha, Rejaul Karim \\ Department of Business Administration, Varendra University, Rajshahi, Bangladesh \\ Email: totamgtru@gmail.com
}

How to cite this paper: Miah, Md.T., Saha, K.B. and Karim, R. (2019) The Role of Private Commercial Bank in Corporate Social Responsibility with Reference to Islami Bank Bangladesh Limited. Open Access Library Journal, 6: e5422.

https://doi.org/10.4236/oalib.1105422

Received: April 24, 2019

Accepted: May 27, 2019

Published: May 30, 2019

Copyright $\odot 2019$ by author(s) and Open Access Library Inc.

This work is licensed under the Creative Commons Attribution International License (CC BY 4.0).

http://creativecommons.org/licenses/by/4.0/

\begin{abstract}
This paper aims at exploring how sharia-based financial institution like IBBL performs corporate social responsibilities in Bangladesh in contrast with conventional banking systems. In the era of globalization, to meet the subsequent monetary crisis, IBBL addresses the social and monetary concerns by undertaking programs along with humanitarian \& catastrophe relief, education, health, sport, arts \& culture to benefit the society. The study reveals a total of 3528 million Taka as CSR expenses by means of examining IBBL five years' annual reports (2013-2017), which addresses the absolute best growth rate in the area of humanitarian (47\%), education (29\%) and health issues (12\%) respectively. It yields a sluggish growth in other sectors in where further investment is pretty recommended for the social welfare of the underprivileged region. By doing this paper, researchers have also suggested some inevitable measures so that pinnacle administration and the government take an ideal guideline to ensure the sustainable development of the country as a whole.
\end{abstract}

\section{Subject Areas}

Business Ethics and Corporate Social Responsibility

\section{Keywords}

CSR, Social Welfare, Growth Rate, Sustainable, IBBL

\section{Introduction}

It's about time we went through a very important issue, which is the talk of the time around the world nowadays. The CSR which stands for Corporate Social 
Responsibility, is a concept practiced by almost all smart firms in each and every corner in this earth. The term "CSR" at first formally was seen in the book "Social Responsibilities of the Businessmen". This concept was referred to the obligations of business persons to follow the policies, to create the policies, or to follow the courses of natural processes that are suitable in terms of the objectives and value of our society [1]. $\mathrm{Zu}$ [2] defined it in short that CSR means companies incorporate social and environmental issues in their business operations and they're dealing with their stakeholders on a voluntary basis. In detailing the basic elements of CSR, [3] delivered to 4-component definition of CSR engrafted in a conceptual framework of Corporate Social Performance (CSP). They were economic, legal, ethical, and discretionary expectations or voluntarism/philanthropy that society has of organizations. To the contrary, Friedman [4] saw CSR as its nature of engagement. The author further added in the CSR concept that engaging in CSR was a problem or struggle between the interests of directors and shareholders. In other words, the managers tried to use CSR as a tool to gain their own social, political, or career agendas at the expense of shareholders. CSR is not just philanthropy, it is more than that. It is a concept whereby companies integrated social and environmental concerns into their business operation and deals with their stakeholders on a voluntary basis. CSR has internal and external patterns. Internal refers to directly related to the physical and psychological working environment of employees [5]. In their article, they [6] stated that from 2008 crisis stems from the financial sector, they set out to explore, within the financial sphere, the possibilities of increasing ethical coordination in public consciousness and thus better fulfilling social expectations. As financial sector, banks also realized the importance of CSR in their business practice. Tsourgiannis [7] described that Corporate Social Responsibility in banks has become a worldwide requirement. Today, by recognizing CSR, banks from all over the world endorse programs of educational, cultural, and environmental, as well as health initiatives. Likewise, they implement sponsorship functions towards fragile groups and charitable not-for-profit organizations. Since the banking sector differs from other economic sectors, its CSR practices are too dissimilar. Here there is more emphasis on responsibility in the areas of bank lending, investment and asset management operations, where combating bribery and money laundering are particularly significant issues, being the key elements of anticorruption efforts, which is an important component of the banks' CSR activities [8]. Further, the banking sector responded relatively late to the challenges of CSR. First, it pays attention to the environmental issues, then to the social issues [9]. In a research titled "CSR Practices and CSR Reporting in Indian banking sector", Wise and Ali [10] mentioned that CSR recognizes an organization's commitment to operating in a socially responsible way. But CSR activities of developing nations are not so rosy. Especially in the financial sector, there is an absence of stringent provisions regarding compliances and reporting CSR. In a paper named "Corporate Governance and Corporate Social Responsibility in Bangladesh with special reference to commercial banks" [11] pointed out that 
Corporate Social Responsibility is related with corporate governance and ethical business procedure. Good corporate governance is desired to underpin effective and efficient corporate social responsibility within organizations. Not only Commercial banks but also other banks in Bangladesh practice CSR as their important activities. Its mission is to set up Islamic Banking through the prelude to welfare oriented banking practice and confirm equity and justice in the field of all financial activities, achieve balanced growth and equitable progress in through diversified investment operations especially in the priority sectors and underprivileged areas of the country. Its goal is to establish and proceed on with the updated banking techniques, ensure soundness and improvement of the economic system based on Islamic principles and become the powerful and expert organization with highly motivated professional, working for the betterment of people, based upon accountability, transparency and honesty in order to ensure stability of economic systems [12]. From the mission and goal of IBBL we can presume that it has a good intension to work for the welfare of human beings. This study has been carried out to look for the CSR practices by IBBL and its significant role for the sustainable development of the economy

\section{Objectives of the Study}

The precise aim and goals of this research have been defined to analyze the role and the practices of CSR of Islami Bank Bangladesh Limited. Apart from this, there are couple of secondary targets have been undertaken which are as follows:

1) To pick out the areas where IBBL has been contributing their CSR expenditures in highest form.

2) To understand the role of IBBL and its contribution to the social welfare of the country.

3) To comprehend the growth rate of each zone of CSR by way of IBBL.

4) To endorse some do's and don'ts to IBBL for similarly improvement of CSR things to do and recommend the areas where greater contribution is inevitable.

\section{Literature Review}

In keeping with global movement, CSR is being seen as the beginning of new competitive edge for the banking sectors of Bangladesh. Banks of Bangladesh practices CSR to not only progress community relationships but also as a birth point of significant commercial benefit [13]. Barclift [14] said that Corporate Social Responsibility (CSR) has possessed an equal importance of corporate financial performance. Most of the people who believe that business decision-making must not only think of profit maximization, but should also willingly contribute to solving social issues, since it is not their economic interest, but their moral responsibility [15]. From a social face, there has been a fresh evolution in recent years, namely serving the helpless. One instance is the micro-credit program through low-income banking [16]. This is absolute that banks are paying more of their CSR activities, said [17] but not so much as their 
salary growth. They also added that common CSR practices in Bangladesh by the different organizations are centered on mainly poverty alleviation, health care, training, charitable activities, cultural enrichment, youth development, women empowerment, supporting sports and music and so on. Gangi, Mustilli \& Varrone said [18] companies invest significant resources in corporate social responsibility, but their attempts to build a global "social brand" may clash with the channeling out of operational strategies at a subsidiary level. Matuszak [19] noted that, the findings of the research were consistent with the internal CSR of banks positively affects citizenship performance and it has a positive predictor of a bank's financial performance which plays a key role in implementing effective CSR programs for external stakeholders. Moreover, this survey showed how CSR engagement in external initiatives could improve a bank's competitiveness because of the relationship between citizenship performance and the positive reputation of a bank. The answers suggested that banks improved their CSR reporting practices have significant deviations in the level of CSR disclosures between banks with a different proprietorship structure. The answers also revealed that there is a significant positive outcome of nearly all variables related to the management board, namely, size, female board leadership and foreign board members of CSR disclosure, whereas all supervisory board variables and all considered ownership variables have no statistically significant impact on CSR disclosure [20] according to Dusuki \& Dar. Sarker [21] identifies several driving forces behind the rising trend towards CSR initiatives like growing market pressure on social and ethical issues, regularity pressure, increased ability of communication and so on. Masud \& Hossain [22] observed that, many common people simply think that CSR practices are merely cosmetic, rhetoric, and in paper only without any real impact on actual life. He also suggested that a real hearing of revenue made from telecom industries through CSR activities may contribute towards a more live able, sustainable and equitable society. Forcadell \& Aracil [23] conducted a survey among 10 commercial banks. They found that $60 \%$ banks participated in prescribing CSR area according to financial act where 100 banks reported their CSR activities. This paper examines the performance of the European banks listed in the DJSI for the period 2003-2013 and analyzes the effect of having a reputation for CSR on performance during a period of economic crisis. A vast amount of literature links CSR, reputation and performance, but few studies have examined the banking sector and the impact of the last recession. Results of the study suggest that, banks' efforts to build a reputation for CSR benefits performance [24]. Ahmed [15] aimed at investigating the corporate social responsibility reporting information of Bangladeshi listed commercial banks and explores the potential effects of corporate governance elements on CSR disclosures by analyzing annual reports of private commercial banks. They also demonstrated that though voluntary, overall CSR reporting by Bangladeshi PCB are rather moderate, however, the varieties of CSR items are really impressive. Roy ([25]) explores how private commercial banks 
practice Corporate Social Responsibility in Bangladesh in conserved the case of Southeast Bank Ltd. In keeping with global movement, CSR is being seen as the source of new competition edge for the banking sectors of Bangladesh. The study based on annual report of 2012 of Southeast Bank Ltd. This study shows that Southeast Bank expenses BDT36.85 million in the year 2012 in the area of education, health, community development, environmental issue, art and culture, sports etc. Rana and their associates said that [26] total CSR expenditure of $\mathrm{AB}$ bank has been increasing over the years, but the growth pace of total CSR expenditure is seen decreasing trend. The increase rate of expenditure on education and environment sector decreased in 2013 compared to the previous years. They further said that CSR practices of Bangladesh are confined within some selected sectors. Lorena [27] found that, Dutch Bangla Bank Ltd. has greatest contribution in CSR activities. DBBL contributes in some selected sectors. These are mainly education, health, disaster, donation sector. It provides with free medical facilities under its "Rural Health Service Program" to the members of the public around the rural branches. DBBL promotes different socio-cultural and sports events. Kilic [28] stated this study concentrated on over the past decades, scholars have paid greater attention in relation between Corporate Social Responsibility and corporate reputation. Yet, despite a growing involvement in this field, such linkages have remained relatively undiscovered in the banking industry and the precise relationship is not open [29] expressed the aim of this study is twofold. The first is to analyze the nature, extent and trend of Corporate Social Responsibility reporting in the Turkish banking industry under five sub-themes, namely, environment, energy, human resources, products and customers and community involvement. The findings of the study also revealed that there is a significant positive effect of size, ownership diffusion, board composition and board diversity on the CSR disclosure of the banks. Haniffa \& Hudaib [30] showed the impacts on different groups across societies, and businesses where firms have different sets of responsibilities to these groups. They also explained the "reverses the lens" to explore these community perspectives and argued that communities see and evaluate CSR terms of the broader immanent effects of the corporate presence rather than simply the intentional CSR programs and prioritize relationships over material outcomes. Islamic financial institutions (IFIs) are regarded as having an ethical identity, and they have different social and economic objectives since the foundation of their business is grounded on religion [31]. The general aim of the IFIs is to lead to the evolution of the economy within the boundary of Islam. Within the range of Sharia (Islamic jurisprudence), IFIs is expected to be conducted by an Islamic economic worldview, which is founded on the precept of social justice and the betterment of society [32] in the research, it is shown that the Islamic banks exhibit an implicit commitment to CSR that is mostly based on informal institutions, whereas conventional banks use explicit CSR strategies as a means to fill the voids in formal institutions. In addition, philanthropy-oriented CSR prevails in Islamic banks, as 
opposed to the CSR actions associated with core business that are pursued by conventional banks. Hossain \& Neogy [33] empirically experimented the statistically significant difference of CSR disclosure among Islamic Sharia-based banking companies in Bangladesh which reveals is no significant difference of CSR disclosure of Islamic banking industry in Bangladesh during the period of 2011-2015 by considering 16 dimensions including Environment, Disaster management, Sports, Shelter, Women, Disabled, Liberation war, Health, Education, Energy, Minorities, Employee, Product responsibility, IT, Community and Government. Overall, so many researches have been conducted only to know the financial performance of banks but few have been researched on understanding the role of CSR in the sustainable development of a country. As a result, the outcome of this research has been tried to benefit the financial and non-financial organizations along with the government to understand the current progress of CSR expenditures across the country and the CSR policy of Islami banking in Bangladesh. Besides, conventional banking, Islami banking systems is said to have high morals and ethics to contribute to the socio-economic welfare of the country. Thus, Researchers have also tried to suggest the amount to contribute to the underprivileged area like housing and shelter, child education and areas where natural calamities are common. Government should also monitor and take some measures so that equitable development through CSR can be formulated and implemented.

\section{Research Methodology}

In this study, applicable articles to CSR, Theoretical researches were reviewed and examined. As being descriptive research, this paper is carried out purely based on the secondary statistics which was gathered from the annual reports of IBBL (2013-2017). These data have been presented in a handy and comprehensible form. Tabular and graphical analysis was operated through Microsoft Word and Excel package.

\section{Data Analysis and Findings}

Though it is observed that all the monetary and banking institutions of the country are at once engaged in performing social responsibilities. Since its inception, Islami Bank Bangladesh Limited is doing as a sharia-compliant financial institution in Bangladesh which commenced operations on 30 March 1983. As an accountable corporate citizen and one of the largest Islamic Bank in the world. IBBL has a responsibility to its stakeholders as well as to the communities in which it acts upon and lives. Their loyalty is based on stakeholders, employees, clients alike and they develop superior value by serving the communities, enhancing commercial enterprise practices and person lives around us. The CSR program of IBBL targets at the welfare and well-being of the people of the earth, the planet itself and all its stakeholders. Holding that in view its CSR focuses on the triple bottom line: People, Planet and Profit. Table 1 depicts 
Table 1. Sector wise CSR expenditure from 2013 to 2017. (Amount in million Tk). Source: Annual report of IBBL (2013-2017).

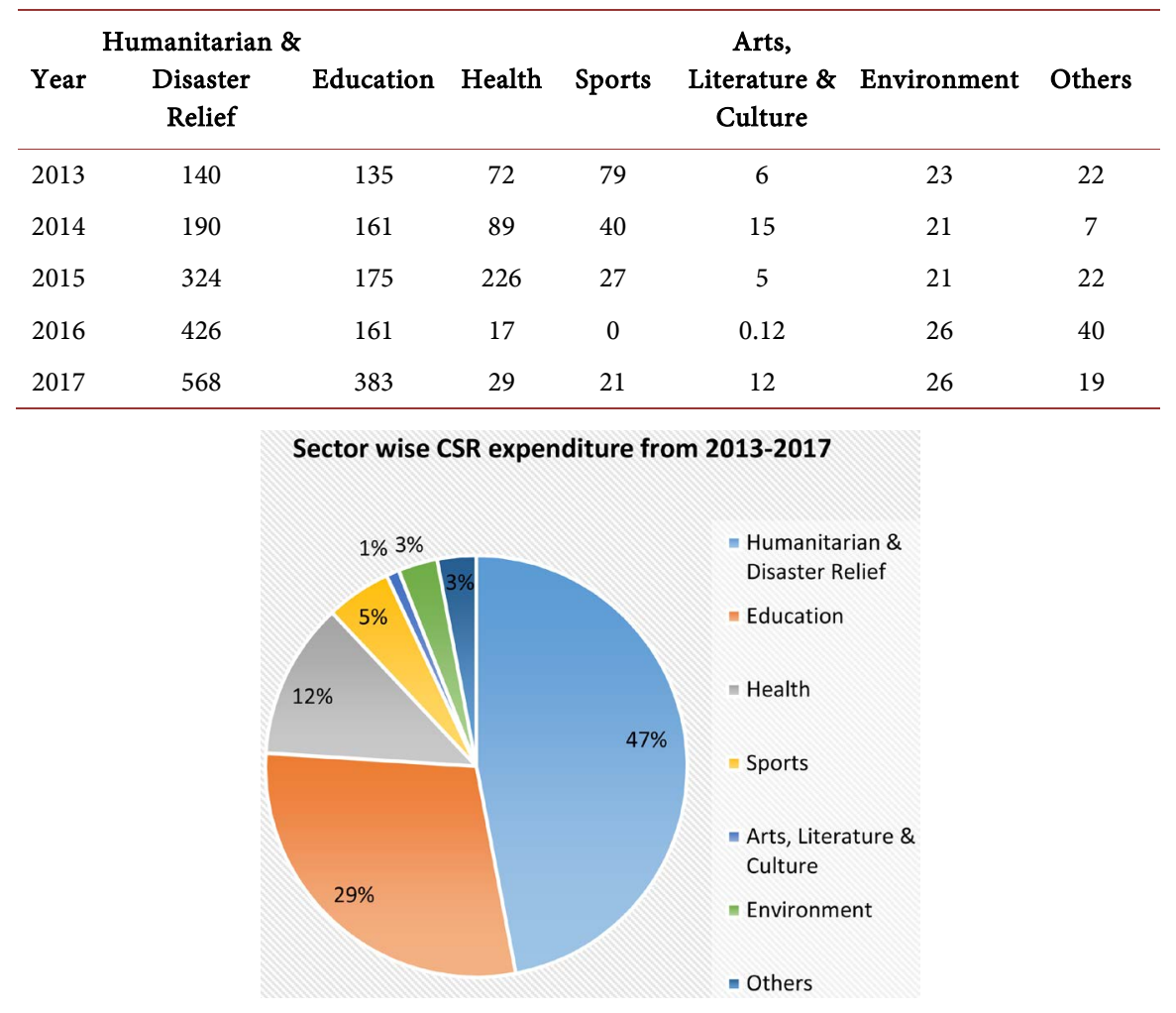

the total CSR expenditures from 2013 to 2017 and the resulted bar char describes the growth rate of each year.

As per the commitment of IBBL to being a responsible corporate entity, they grant and assist volunteers in all communities around the country, especially the less fortunate segments of the community, including humanitarian \& disaster relief, education, environment, health, arts \&culture as properly as others sector. As a result, the listed above figure demonstrates their CSR activities which exhibit an upward style in almost every year besides for a decrease trend in the year of 2016 which the quantity diminished via 16\% (Figure 1). Total CSR expenditure of this financial institution was 476 million, 525 million, 800 million, 671 million and 1058 million in 2017 respectively. An amount of the complete 3530 million for 6,043,974 beneficiaries was spent through IBBL from the year of 2013-2017 which is the absolute best in wide variety among all other banks.

\subsection{Sector Wise Csr Expenditure from (2013-2017)}

\subsubsection{Humanitarian and Disaster Relief}

As a conscious corporate citizen, Islami Bank Bangladesh Limited, furnished monetary funding for a quantity of environmental lawsuits over the long time. As they believe that catastrophe can take anywhere. No nation, rich or poor, is immune from dangers of accidents and mess ups inflicting deaths and injuries, destructions to houses, belongings like disrupting financial things to do and livelihoods of families. 


\section{Direct CSR Expenditure Reported BY IBBL}

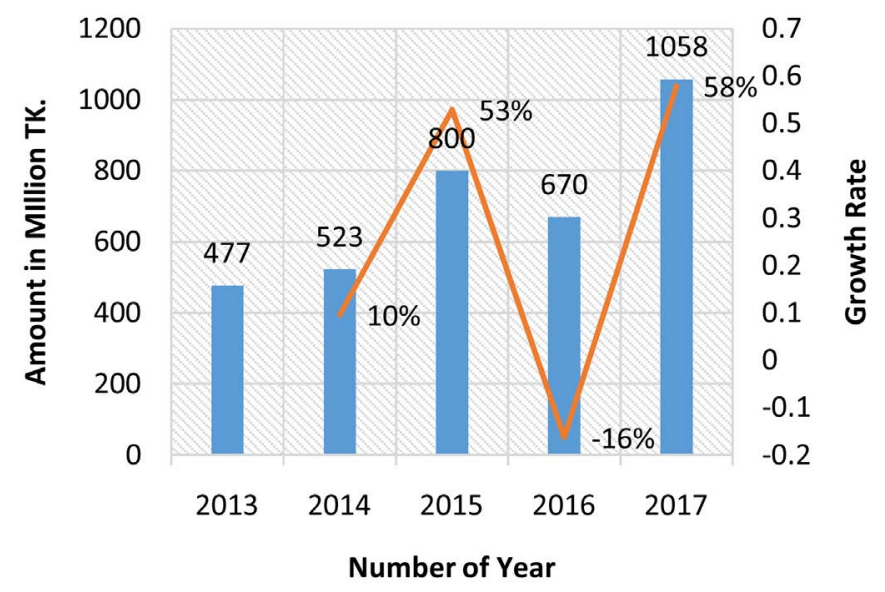

Figure 1. Total CSR expenditure of IBBL and growth rate. Source: Annual report of IBBL (2013-2017).

Figure 2 demonstrates that IBBL spends 140 million amount in 2013, 10 million in 2014, 324 million in 2015, 426 million in 2016 and 568 million in 2017 which is the highest expenditure in that year. Over the year, people of this land are fighting with poverty and many other natural disasters. Being a corporate citizen of the country, IBBL always stands beside the distressed man. By devising special deposit products, extending financial inclusion and providing financial assistance, the Bank discharges its obligations towards the short and less fortunate sections of the company. The disaster relief program includes winter cloths distribution, Donation to PM's relief fund, distribution of Tohfa-e-Ramadan, sacrificial meat distribution, rehabilitation program etc.

\subsubsection{Education}

Education is a pre-requite for the overall development of the country. Keeping this view in mind, IBBL has been engaged with the promotion of education sector of the country from the beginning. IBBL spent an amount of Tk.1015 million for 51,773 beneficiaries from 2013-2017 for this purpose. The following graph (Figure 3) shows a sluggish growth for the education sector from the year 2013 to 2016 but there is a high growth in the year of 2017 by $138 \%$.

Apart from this, IBBL has been providing scholarship to the very poor 2700 students (1500 in HSC, 800 in Graduation and 400 in Special Scholarship level) securing GPA 5 in SSC \& HSC examinations under its direct Scholarship program. The Scholarship is provided to the students @ Tk. 2000/-per month for 2 years for HSC level with Tk. 3000/-at a time for purchasing Books per year. Tk. 4500/-(Urban) \& Tk. 3000/-(Rural) per month for 3 to 5 years for Graduation level with Tk. 5000/- at a time for purchasing Books per year. In addition, Special scholarship is allowed to 400 meritorious but poor students in different educational institutions. They also contributed to "PROYASH" which is an institute run under the patronization of Bangladesh Army for the well-being of children with exceptional needs and disability. During this period IBBL donated 


\section{Growth rate of humanitarian \& Disaster relief}

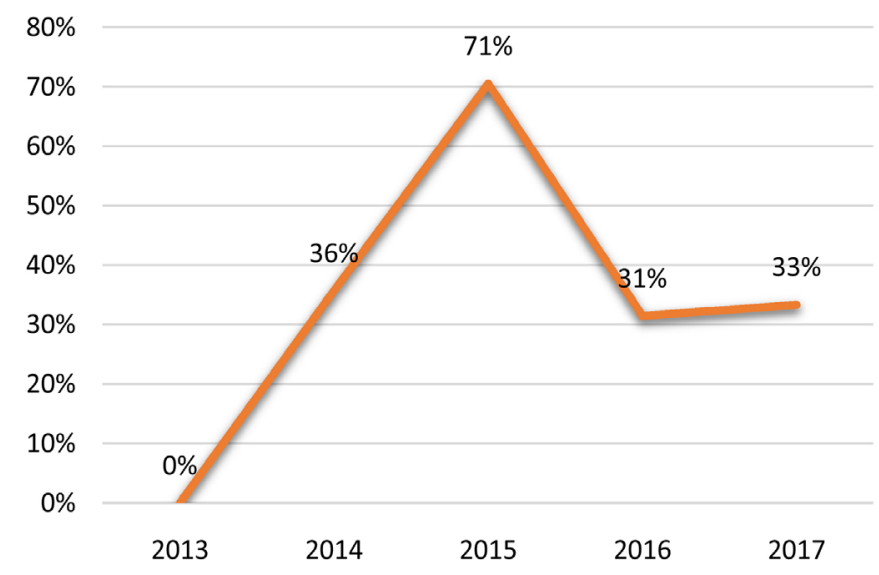

Figure 2. CSR spending of IBBL on humanitarian \& disaster relief. Source: Annual report of IBBL bank (2013-2017).

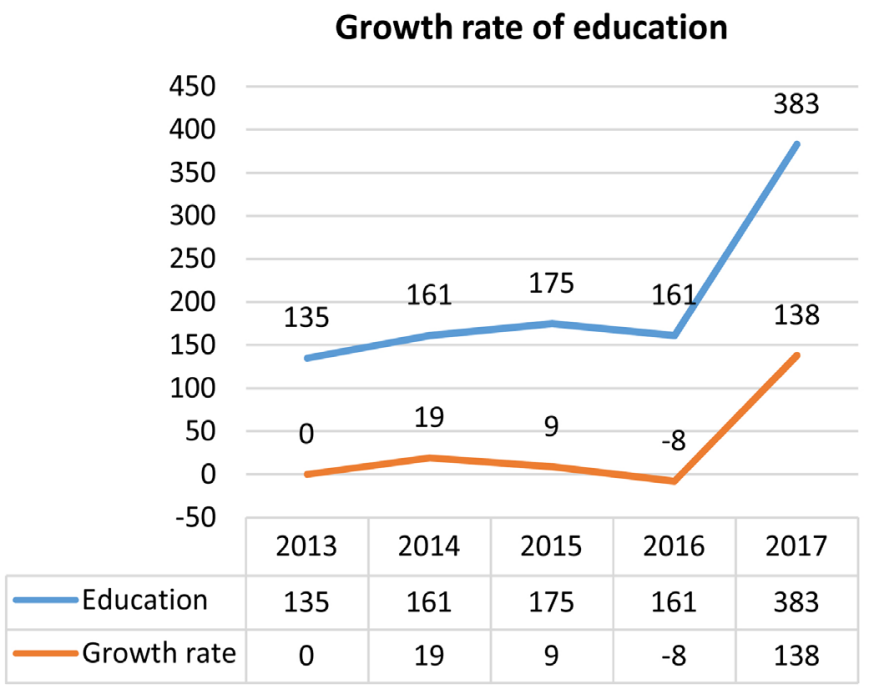

Figure 3. Source: Annual report of IBBL (2013-2017).

Tk. 35.00 million to "PROYASH", Jessore. Considering the disabled children as an asset of the fellowship, the Bank stands beside the authority of Proyash for fuel! element of their demand. During this period IBBL donated Tk. 5.00 million to Rabeya Ali girls' school \& college, chandrawdigolia, Gopalgonj, Tk.5.00 million to PanchkholaMukti senior high school \& College, Madaripur and Tk 2.5 Million to Fakir Sohrab Ali Collage, Mymensingh.

\subsubsection{Health Program}

Health care is a basic need of all societies. But people are facing here a perilous state of affairs due to a hazardous Medicare system of the state. Seeing this, IBBL takes several initiatives in individual and organizational level for growing health sector of Bangladesh.

IBBL spent an amount of Tk. 433 million for 320,128 beneficiaries from 2013-2017 for this purpose to donate Tk. 87.41 million to The International 
Centre for Diarrheal Disease Research, Bangladesh (icddr, b) Dhaka, Tk. 20.00 million to Holy Family Red Crescent Medical College Hospital and Tk.35.00 million to Anjuman Mu! Idul Islam, Kakrail, Dhaka. In the graph, it depicts a lowest amount of 17 million which have been spent in health sector in the year 2016 and the highest expenditure done by IBBL in health sector was 226 million in the year of 2015. It clearly shows a sluggish growth in health (Figure 4).

\subsubsection{Sports, Arts \& Cultural Program}

Sports programs make a nation physically and mentally sound and healthy. Engaging with this type of works young people could be able to avoid many bad involvement, as like taking drugs, involving forbidden underworld parties, hijacking money from innocent people etc. This is why IBBL sponsors various sports events every year. IBBL encourages sports activities of its employees. An amount of Tk. 167 million was spent by IBBL from 2013-2017 for this purpose. From Table 1, which depicts a lower trend in this sector.

\subsubsection{Arts and Cultural Program}

In addition to its contribution to the basic needs of the community, IBBL also takes part in the creative and entertainment arena of the country. To build nation's positive image, it very often sponsors various cultural events every year. It endeavors to protect and preserve national heritage and originality of indigenous art and culture of the society by contributing to the restoration work of building and sites of historical interest and renowned artworks. It also promotes and develops traditional arts and handicrafts, rural and nationally recognized sports and games. IBBL spent an amount of Tk. 38 million from 2013-2017 for this purpose.

Environmentalism at IBBL: The fundamental theme of environmental accountability is to protect the surroundings from destruction with a view to keep it healthful for future generation. Recently, the issue of climate change is being

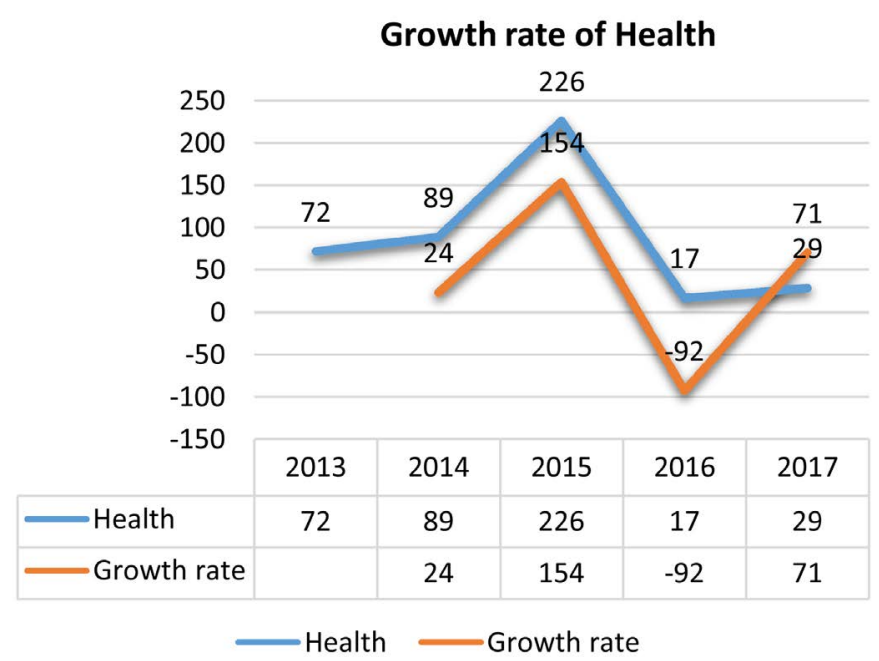

Figure 4. CSR spending on Health sector by IBBL. Source: Annual report of IBBL (2013-2017). 
considered seriously all over the world. It is recognized that Bangladesh being a country of southern delta is under serious risk from natural disaster. IBBL contributed a quantity of Tk. 117 million from 2013-2017 for environmental troubles of the country.

Others: Despite making the above named areas, IBBL is also devoted to guard and care its inner and outside environments. Sustainability encompasses within itself aside from health, education, IBBL took projects of giving humans a danger of a more honorable lifestyle with the aid of providing nutrients, shelter, garb and possibly still to an increased extent. From the year of 2013-2017, a complete of 110 million has been expended. The table also provides an upward tendency in this sector.

\section{Recommendation \& Conclusion}

From this assessment, it can be said that CSR activities play a significant contribution to the overall socio-economic development of a country. Bangladesh is no exception from this as the government alone can progress the development. Corporate organizations can conduct social and benevolent activities under CSR program for enhancing balanced socio-economic development with the help of government. Being the first private bank in Bangladesh, this study recommends some dos for taking further initiatives and for the $21^{\text {st }}$ century need and demand. The amount contributed by IBBL for CSR activities is increasing but the overall growth rate is lower in trend. The top management should think the equal distribution of resources to ensure sustainability. Apart from humanitarian \& disaster relief, education and health, IBBL must contribute to the other sectors for socio-economic development of the country. It could provide a community with a soft loan or economic aid to start a mini-farm, cattle and poultry raising or fish farming etc. It can also provide assistance for the shelterless people or building housing facilities for the underprivileged child's. It can help remove barriers to productive activity by providing one or several marketing channels to generate demand for their product. To sum up, becoming aware of its social responsibilities, IBBL has no choice but to implement CSR policies for the sustainable development in the $21^{\text {st }}$ century of the country. Though this study does great contribution to understand the current and future growth of social responsibilities, future research must have been done as it lacks primary data and the constraint of bureaucratic problems as well as data sufficiency. It is also mentionable to operate more research work on Govt. supervision and guidelines to CSR policy. Moreover, it reveals that the government and the corporation should build a cordial relationship for deepening the CSR contribution. As a part of society, it needs to take part in different obligations especially economic, social, environmental, philanthropic and ethical duties to reform the society where IBBL will be a role model of other financial institutions in Bangladesh.

\section{Conflicts of Interest}

The authors declare no conflicts of interest regarding the publication of this 
paper.

\section{References}

[1] Bowen, H.R. (1953) Social Responsibilities of the Businessman. Harper \& Row, New York.

[2] Zu, L. (2009) The Effects of Managerial Values on Socially Responsible Restructuring. In: Corporate Social Responsibility, Corporate Restructuring and Firm's Performance: Empirical Evidence from Chinese Enterprises, Springer-Verlag, Berlin, Heidelberg.

[3] Carroll, A.B. (1979) A Three-Dimensional Conceptual Model of Corporate Performance. Academy of Management Review, 4, 497-505.

https://doi.org/10.5465/amr.1979.4498296

[4] Friedman, M. (1970) The Social Responsibility of Business Is to Increase Its Profits. The New York Times Magazine, September 13, 1970. The New York Times Company.

[5] Turker, D. (2009) Measuring Corporate Social Responsibility: A Scale Development Study. Journal of Business Ethics, 85, 411-427.

https://doi.org/10.1007/s10551-008-9780-6

[6] Lentner, C., Szegedi, K. and Tatay, T. (2015) Corporate Social Responsibility in the Banking Sector. Public Finance Quarterly, 60, 95-103.

[7] Tsourgiannis, L., Kazana, V., Karasavvoglou, A., Nikolaidis, M., Florou, G. and Polychronidou, P. (2013) Exploring Consumers' Attitudes Towards Wood Products That Could Be Derived from Transgenic Plantations in Greece. Procedia Technology, 8, 554-560. https://doi.org/10.1016/j.protcy.2013.11.078

[8] Viganò, F. and Nicolai, D. (2009) CSR in the European Banking Sector: Evidence from a Survey. In: Barth, R. and Wolff, F., Eds., Corporate Social Responsibility in Europe: Rhetoric and Realities, Edward Elgar, Cheltenham, 95-108. https://doi.org/10.4337/9781848447233.00017

[9] Sharma, N. (2011) CSR Practices and CSR Reporting in Indian Banking Sector. International Journal of Advanced Economics and Business Management, 1, 58-66.

[10] Wise, V. and Ali M, M. (2009) Corporate Governance and Corporate Social Responsibility in Bangladesh with Special Reference to Commercial Banks. AIUB BUS Econ Working Paper Series No. 2009. 05.

[11] https://www.islamibankbd.com/abtIBBL/abtIBBLAtaGlance.php

[12] Ahmed, M.K., Jobair, M. and Azad, M.M.H. (2013) Corporate Social Responsibility Practices of Commercial Banks in Bangladesh: A Case Study on Southeast Bank Ltd. IOSR Journal of Business and Management, 12, 13-18. https://doi.org/10.9790/487X-1211318

[13] Yeung, S. (2011) The Role of Banks in Corporate Social Responsibility. Journal of Applied Economics and Business Research, 1, 103-115.

[14] Barclift, Z.J. (2012) Corporate Social Responsibility and Financial Institutions: Beyond Dodd-Frank. Banking \& Financial Services Policy Report, 31.

[15] Chiu, T.K. (2014) Putting Responsible Finance to Work for Citi Microfinance. Journal of Business Ethics, 119, 219-234. https://doi.org/10.1007/s10551-013-1626-1

[16] Alam, S.M.S., Hoque, S.M.S. and Hosen, M.Z. (2010) Corporate Social Responsibility of Multinational Corporation in Bangladesh: A Case Study on Grammen Phone. 
Journal of Pathuakhali Science and Technology University, 2, 51-61.

[17] Asmussen, C.G. and Fosfuri, A. (2019) Orchestrating Corporate Social Responsibility in the Multinational Enterprise. Strategic Management Journal, 40, 894-916. https://doi.org/10.1002/smj.3007

[18] Gangi, F., Mustilli, M. and Varrone, N. (2019) The Impact of Corporate Social Responsibility (CSR) Knowledge on Corporate Financial Performance: Evidence from the European Banking Industry. Journal of Knowledge Management, 23, 110-134. https://doi.org/10.1108/JKM-04-2018-0267

[19] Matuszak, Ł., Różańska, E. and Macuda, M. (2019) The Impact of Corporate Governance Characteristics on Banks' Corporate Social Responsibility Disclosure: Evidence from Poland. Journal of Accounting in Emerging Economies, 9, 75-102. https://doi.org/10.1108/JAEE-04-2017-0040

[20] Dusuki, A.W. and Dar, H. (2005) Does Corporate Social Responsibility Pay Off? An Empirical Examination of Stakeholder Perspectives. 2nd International Conference on Business Performance, London, Vol. 22.

[21] Sarker, M.F.H. (2014) Corporate Social Responsibility of Telecom Industries in Bangladesh: Rhetoric vs. Realities. Social Sciences, 3, 199-207. https://doi.org/10.11648/j.ss.20140306.13

[22] Masud, M. and Hossain, M. (2012) Corporate Social Responsibility Reporting Practices in Bangladesh: A Study of Selected Private Commercial Banks. IOSR Journal of Business and Management, 6, 42-47. https://doi.org/10.9790/487X-0624247

[23] Forcadell, F.J. and Aracil, E. (2017) European Banks' Reputation for Corporate Social Responsibility. Corporate Social Responsibility and Environmental Management, 24, 1-14. https://doi.org/10.1002/csr.1402

[24] Khan, H.U.Z. (2010) The Effect of Corporate Governance Elements on Corporate Social Responsibility (CSR) Reporting: Empirical Evidence from Private Commercial Banks of Bangladesh. International Journal of Law and Management, 52, 82-109. https://doi.org/10.1108/17542431011029406

[25] Roy, J.D. and Mahmud, M.A.L. (2015) Corporate Social Responsibility in the Banking Sector of Bangladesh: A Case Study on AB Bank Limited. Global Journal of Management and Business Research, 15.

[26] Rana, M.M., Kalam, A., Halimuzzaman, M., Kalam, A. and Halimuzzaman, M. (2012) Corporate Social Responsibility (CSR) of Dutch-Bangla Bank Limited: A Case Study. Bangladesh Research Publication Journal, 7, 241-247.

[27] Lorena, A. (2018) The Relation between Corporate Social Responsibility and Bank Reputation: A Review and Roadmap. European Journal of Economics and Business Studies, 4, 7-19. https://doi.org/10.2478/ejes-2018-0034

[28] Kiliç, M., Kuzey, C. and Uyar, A. (2015) The Impact of Ownership and Board Structure on Corporate Social Responsibility (CSR) Reporting in the Turkish Banking Industry. Corporate Governance, 15, 357-374. https://doi.org/10.1108/CG-02-2014-0022

[29] McLennan, S. and Banks, G. (2019) Reversing the Lens: Why Corporate Social Responsibility Is Not Community Development. Corporate Social Responsibility and Environmental Management, 26, 117-126. https://doi.org/10.1002/csr.1664

[30] Haniffa, R. and Hudaib, M. (2007) Exploring the Ethical Identity of Islamic Banks via Communication in Annual Reports. Journal of Business Ethics, 76, 97-116. https://doi.org/10.1007/s10551-006-9272-5

[31] Dusuki, A.W. and Dar, H. (2007) Stakeholders' Perceptions of Corporate Social 
Responsibility of Islamic banks: Evidence from Malaysian Economy. Islamic Economics and Finance, 249.

[32] Racil, E. (2019) Corporate Social Responsibility of Islamic and Conventional Banks: The Influence of Institutions in Emerging Countries. International Journal of Emerging Markets. https://doi.org/10.1108/IJOEM-12-2017-0533

[33] Hossain, M.S. and Neogy, T.K. (2019) The Current Status of Corporate Social Responsibility Disclosure of Islamic Shari-Based Banking Companies in Bangladesh. American Journal of Trade and Policy, 6, 7-12. 